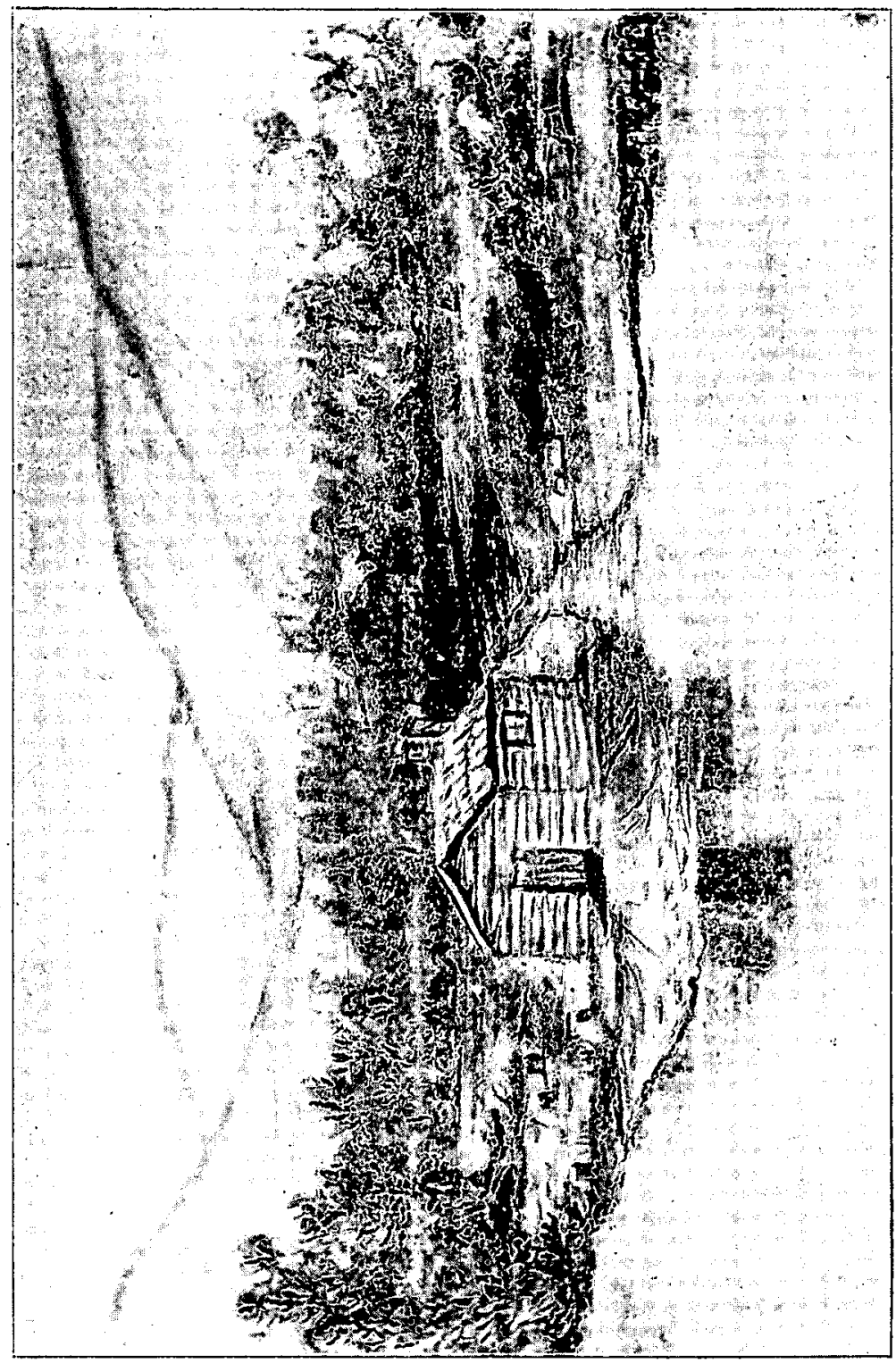

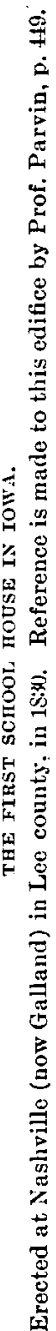




\section{THE EARLY SCHOOLS AND TEACHERS OF IOWA.}

BY T. S. PARVIN, LI. D.

Every now and then a new error comes to the front in the newspapers of the day: First one and then another claims to have "taught the first school in Iowa," or erected "the first school house." Having thoroughly investigated this matter I have from time to time corrected these errors until I have abandoned the hope of keeping the newspaper press correct upon the subject.

In the Annals of Iowa, Vol. 3, No. 1, April, 1897, under the heading "Notable Deaths," I find an editorial, evidently based upon a newspaper article first appearing in The Fairfield Ledger, a few weeks later repeated in The Burlington Hawkeye and other papers of the State. The paragraph reads:

Susan Smith Russell, the first woman teacher in Iowa, and an old pioneer of Jefferson, died at that place Feb. 22, 1897. In 1837 she came to old Fort Des Moines and began teaching in the barracks; this was one year after the territory of Wisconsin had been taken from Michigan territory. While still engaged in this work Iowa was made a separate territory (July 4,1838 ) and consequently Mrs. Russell had the honor of being its first woman teacher.

Finding so grave an error in a leading historical magazine of the State $I$ at the time called the editor's attention to the incorrectness of the statement, which was overlooked, bowever, in the subsequent numbers as issued.

It is not too late to correct an error, as one of these days some one will be re-writing-I say re-writing because $I$ have written-the history of "early education in Iowa," and will naturally turn to The ANNALS and Historical Recond as affording the best evidence from which to write such history.

In the winter of 1888-89 I wrote and published my "History of the Early Schools and Education in Iowa, 1830-59," and in the preparation of this work I made a thorough study and examination into all the evidence accessible at that time, (and I may here add none has become accessible since to 
- even enlarge upon the subject then discussed), and published not only the facts but the authorities upon which my statements were based. The matter has not lost any of its interest during the seven or eight years that have elapsed since the publication of that volume, and I may briefly quote some paragraphs from that history and so be able to refute the statement quoted and give honor to whom honor is due.

There was a lady teacher who taught school for some two quarters or more, three year's preceding Mrs. Russell's coming to Iowa, and so of course antedates her in her profession. I quote the following paragraph from my history :

"Mrs. Rebecca Palmer, the first lady teacher in Iowa, opened her school in Ft. Madison, Lee County, in the summer of 1834." In another paragraph entitled "First Things," arranged according to date, I fiud this entry: "1834, September-First lady teacher, Mrs. Rebecca Palmer, Ft. Madison."

This was while the Iowa District west of the Mississippi river, with Wisconsin, constituted a part of the Territory of Michigan; Wisconsin was organized as a territory in 1836; Iowa in 1838.

The information upon which I based these statements I obtained from the County History of Lee County, and from personal letters from Captains Washington Galland, who served during the Rebellion, and J. W. Campbell, who was Captain of one of the leading packets upon the Mississippi river running from Keokuk to Rock Island-both of them then and now citizens of Lee County-both of them having located with their parents in that county as early as the fall of 1830 , and both pupils in that first school taught by Berryman Jennings.

Since that time I have received some very strong and conclusive evidence upon the subject-a letter from $L$. 'D. Palmer, from which I quote:

Vermiliton, South Daкота, May 25, 1897.

Dear Bro. Parvin:-My son Mark M. handed me the Des Moines Saturday Review containing your article "Pioneer School Days Prior to 1840," and I find your notice of "Bro. Berryman Jennings as the first school 
muster of Iowa, winter of 1830, at Nashville, Lee Co., Territory of Iowa, and also of Mrs. Rebeca Palmer as the first female teacher at or near Ft. Madison in the fall of 183t." You say "you were personally acquainted with Bro. Berryman Jennings, but was not with Mrs. Palmer."

I wish to inform you that Jennings and Mr. Doolittle, my wife's father, were brothers-in-law, by marriage to sisters Caroline and Massy White, and my first marriage occurred at Berryman Jennings' residence in Burlington, Iowa, March 5, 1845, the very day Polk was inaugurated President of the United States.

Mrs. Rebecea Pulmer was my mother and we lived on a farm one and a hulf miles enst of Ft. Madison on the stage road to Burlington. At this time, I remember the period, she kept school (18:4t-5) going to the school house one and a half miles north-east, through the winds and snow, and wearing rubber boots in the spring to get through to the school house. I was then thirteen years old, and it was our first winter in Iowa on the "Black Hawk Purchase." I was well acquainted with the chief and his successor, Keokuk, appointed by the Government. I had a good opinion of Black Hawk and remember that he had a head like Gen. Zachary Taylor's, and it was generally understood that neither ever knew when they were defeated. I did not wonder that Taylor beat Santa Anna at Buena Vista, Mexico, which carried his nomination and election as President in 18 t.8.

A word as to the writer of the letter from which the above is quoted: I first became acquainted with Mr. Palmer in 1846, the year Iowa became a state; he was then a prominent merchant in the city of Ft. Madison. Soon after, during the forties, he removed to Muscatine, where I was then residing, and further engaged in the mercantile business, which he continued for many years, when later he removed to Yankton, Dakota, where he again established himself as a dry goods merchant. $\mathrm{Mr}$. Palmer was a prominent politician, business man and Mason, having served his fellow-citizens as postmaster at Yankton, Dakota, during the Cleveland administration. He only died last year (October, 1897).

This tells conclusively the facts, that-Mrs. Russell was not "the first woman teacher in Iowa," by nearly three years; and further that Mrs. Rebecca Palmer was not only her predecessor, but was "the first lady teacher in Iowa," dating back to the period when it was a constituent part of Michigan territory. Iowa was a part of Wiscousin territory when Mrs. Russell taught her school; and she was not even the 
second school teacher of her sex, as others too had preceded her.

As my History is not accessible to the general and teaching public I may quote a few other passages: I stated that "Berryman Jennings tanght the first school (within what are the present territorial limits of Iowa) during the months of October, November and December, 1830, at what is now known as Nashville, Lee Co." From a letter received from Berryman Jennings, whom I personally knew, (he having been made a Mason in my old Lodye, No. 1, at Burlington,) dated Oregon City, Oregon, November 28, 1884, he wrote:

Dear Sir and Brother:-I was residing on the "Half Breed Tract" now part of Lee County, in 1830. Dr. Isauc Galland (father of Washington Galland) an eminent physician and citizen resided six or eight miles above the present site of Keokuk, on the Mississippi river, near where resided several American citizens who had children of a school age. The Doctor prevailed upon me to teach a three month's school. Dr. Galland furnished rooms, fuel, furniture, and board in his family. This school room was like all other buildings in that new country, a log cabin built of round logs, or poles, notched close and mudded for comfort, logs cut out for doors and windows, and also for fire-places. The jamb back of the fire-places was of packed dry dirt, the chimney topped out with sticks and mud. This cabin like all others of that day was covered with clap-boards. This was to economize time and nails, which were scarce and far between. There were no stoves in those days and the fire-place was used for cooking as well as comfort.

The entire letter is full of interesting listorical items, but is too long for publication in this connection.

In the preparation of my History I published chapters from time to time in the newspapers inviting criticisms and corrections and so learned through the Burlington papers that a Mr. I. K. Robinson of Mendota, Illinois, claimed the honor of having taught the first school in Iowa, whereupon I wrote him and received a letter in reply from which I make some extracts :

Mendota, Ill., Jan. 30, 1887.

Dear Sir and Brother:-(he too'a Mason) In answer to your letter of inquiry of the 17th inst., about "the early schools of Iowa," I reply: I commenced teaching a school December' 1 , 1830, (this was two months later than Mr. Jennings commenced his school) in the employment of a Mr. Stillwell, who was then owner of a warehouse and wood-yard at the present 
site of Keokuk, Iowa. The school was continued sometime into the spring of 1831 .

He then further adds: "If there were any schools in Iowa previous to this one, I do not know where or by whom taught."

It seems a little singular that there should have been two schools in Iowa during that month of December, and both of them in the County of Lee, and within less than ten miles of each other, and yet neither teacher knowing of the other or of his work.

With some of Mr. Robinson's pupils who afterwards became prominent citizens of Keokuk, I was personally acquainted, and from them received verifications of the statement made in this letter. So far as I know all of the pupils of Mr. Robinson are now decensed and only two of those who were pupils of Mr. Jennings are living, Captains Washington Galland and J. W. Campbell of Lee county.

Recently I received from Capt. Galland a good photograph from a sketch made from memory by himself of that school house, which I forwarded to the editor of THE AnNals and which will no doubt appear in an early number.

Setting aside this first school house referred to by Hon. Berryman Jennings, as having been used also for dwelling purposes, the first school house proper (also a log building) was erected in December, 1833, at Burlington, by Dr. W. R. Ross, who was the first postmaster of that city and the second, I believe, in Iowa-his predecessor in point of time; though' at another place, being Mr. Prentiss.

Raturoad Iron for Iowa.-The ships Edward Wyman and Wm. Nelson have arrived at New Orleans from England. with cargoes of Railroad Iron for the Keokuk and Ft. Des Moines Railroad. The Directors and Managers of the Railroad deserve credit for their business tact, indomitable per-. severance and success in providing the means to secure its construction. What an advantage it is to a Railroad, as it is to every enterprise, to be directed by. men of business capacity!-Dubuque Herald, July 18, 1860. 
Copyright of Annals of Iowa is the property of State of Iowa, by \& through the State Historical Society of Iowa and its content may not be copied or emailed to multiple sites or posted to a listserv without the copyright holder's express written permission. However, users may print, download, or email articles for individual use. 